by private investigators, though various laboratories abroad, such as those at the Fogg Art Museum, Harvard University, and at the Technical High School, Munich, have attacked the subject systematically. One of the main aims of the new Department will be the co-ordination of its results, with the view of publication, with these obtained in other centres, with which close relations will be cultivated. The head of the new Department and Laboratory is Dr. P. D. Ritchie, who will have the benefit of the knowledge and experience of a permanent advisory committee consisting of a number of prominent men of science and art experts. It is hoped that the Department will be in active operation by October, though no problems can be dealt with before that date.

\section{International Anthropology and Ethnology}

THE first session of the International Congress of Anthropological and Ethnological Sciences was opened by H.R.H. Prince George at University College, London, on July 30. The Congress is the outcome of a movement initiated more than twenty years ago, when in 1912, after the London Meeting of the International Congress of Americanists, a small international committee was appointed by the Royal Anthropological Institute to organise such a Congress. As a result of no little negotiation and correspondence, it was then arranged that a Congress should take place in 1916. Owing to the War, the Congress did not meet, and the proposal fell into abeyance, until in the course of the discussion of arrangements for the International Congress of Prehistoric and Protohistoric Sciences, which met in London in 1932, it emerged that the need for an international meeting ground for the discussion of the problems of ethnology was urgently felt. Experience gained by the inclusion of an ethnological section at the archæological congresses organised after the War by the French Institut d'Anthropologie had proved to the satisfaction of most of those who had taken part that nothing short of an independent congress would prove satisfactory. Many, with good reason, were reluctant to add to the already large number of international scientific congresses; but the almost overwhelmingly heavy programme submitted at this first session is a sufficient proof of the wisdom of the decision. Not merely the number and the variety of the communications, but also the number of joint diseussions between two or more sections-thirteen discussions in all-shows that, even within the limits laid down by those responsible for the organisation of the programme, the debatable questions in ethnology, which it is felt desirable to ventilate by open discussion, are numerous.

ON the opening, the Congress numbered more than a thousand members, and delegates from no less than forty-two different countries were present when Lord Onslow delivered his presidential address at the inaugural meeting. America, both North and South, was well represented, owing to the approximation of the date to that of the forthcoming European session of the International Congress of Americanists later in the month. This is a coincidence which the promoters had in view as a regular recurrence every four years, when the present year was chosen to initiate the series. As the presence of so many foreign anthropologists of distinction is not likely to occur again for a long time to come, every effort had been made to show them as much as possible of the ethnographical and archæological treasures of our public and private collections, while a number of special exhibits had been arranged. Among these, one of the most striking was the exhibit of material brought back by Miss G. Caton-Thompson and Miss E. W. Gardiner from their investigations on behalf of the Royal Anthropological Institute at El Khargeh in Egypt. The exhibits illustrate the classification of stone implements into seven periods of the Stone Age, the fossil mound springs which have demonstrated the existence of two pluvial periods, and have afforded evidence not only of the character of the water supply but have also provided data bearing on the relation of prehistoric tools to fossil vegetation, of which the exact period and determination had hitherto defeated investigators. This exhibition will be on view to the public after the Congress for a period of three months. The British Museum also arranged an exhibit especially for American visitors, which included the famous Maudslay Maya plaster casts and examples of the antiquities obtained by the Museum's expeditions to British Honduras. Special interest also attached to the prehistoric pottery brought by Sir Aurel Stein from Baluchistan and Persia, in view of the subject of the Huxley Memorial Lecture, which he delivered on July 31, before the Congress.

\section{Exhibits from Tell Duweir, Palestine}

IN order to afford those attending the International Congress of Anthropological Sciences in London an opportunity of viewing the antiquities from Tell Duweir, the Exhibition of the Wellcome Archæological Research Expedition in the rooms of the Palestine Exploration Fund, Manchester Square, remained open until August 3. Much interest was aroused by the exhibits, the inscribed ewer naturally attracting a great deal of attention. Further fragments of the ewer have been found among the material brought from Palestine, and these have added definition to its form, while the line of decora. tion is now almost continuous. A card exhibited with the ewer gave the alternative readings which have been proposed. Even more impressive were the relics from the sanctuary shrine in the fosse, of which the destruction is dated by the Rameses II plaque as not earlier than the first half of the thirteenth century B.C. The preservation in situ, and in some instances intact, of the appointments of the shrine gives the find a unique character. These objects, including the benches for offerings, the libation jar and offerings bin and the like, were displayed in and around a model reconstructed from squeezes. This exact record of a remarkable cult-object reflects the greatest credit on the initiative and technical skill of the members of the expedition. 